\title{
APLP1 wt Allele
}

National Cancer Institute

\section{Source}

National Cancer Institute. APLP1 wt Allele. NCI Thesaurus. Code C119730.

Human APLP1 wild-type allele is located in the vicinity of 19q13.1 and is approximately 12 $\mathrm{kb}$ in length. This allele, which encodes amyloid-like protein 1 , is involved in signal transduction. 